\title{
Paleolimnological records of regime shifts in lakes in response to climate change and anthropogenic activities
}

\author{
Linda Randsalu-Wendrup • Daniel J. Conley • \\ Jacob Carstensen $\cdot$ Sherilyn C. Fritz
}

Received: 9 July 2013 / Accepted: 29 February 2016/Published online: 16 March 2016

(C) The Author(s) 2016. This article is published with open access at Springerlink.com

\begin{abstract}
Regime shifts in lake ecosystems can occur in response to both abrupt and continuous climate change, and the imprints they leave in paleolimnological records allow us to investigate and better understand patterns and processes governing ecological changes on geological time scales. This synthesis investigates paleolimnological records that display apparent regime shifts and characterizes the shifts as either smooth, threshold-like or bistable. The main drivers behind the shifts are also explored: direct climate influence on lakes, climate influence mediated through the catchment, lake ontogenetic processes and/or anthropogenic forcing. This framework helps to elucidate the relationship between driver and regime shift dynamics and the type of imprint that the associated regime shifts leaves in sediment
\end{abstract}

L. Randsalu-Wendrup ( $₫)$ · D. J. Conley

Department of Geology, Lund University, Sölvegatan 12, 22362 Lund, Sweden

e-mail: linda.randsalu@wendrup.se

D. J. Conley

e-mail: daniel.conley@geol.lu.se

J. Carstensen

Department of Bioscience, Aarhus University,

P.O. Box 358, 4000 Roskilde, Denmark

e-mail: jac@dmu.dk

\section{S. C. Fritz}

Department of Earth and Atmospheric Sciences, University of Nebraska, Lincoln, NE 68588, USA

e-mail: sfritz2@unl.edu records. Our analysis of the limited sites available (22 sites) show that smooth regime shifts are characterized with forcing and response variables acting on similar time scales, whereas regime shifts that demonstrate a threshold like response or a hysteresis response occur on shorter time scales than changes in drivers. The temporal resolution of the record, a common concern in paleo records, limits identification of the timing and rate of the regime shifts. When detected, past regime shifts offer rich opportunities to understand ecosystem responses to climate and other changes and to evaluate the mean state and natural variability of lake ecosystems on time scales of decades to millennia. There are a number of remaining challenges in understanding regime shifts and ecosystem dynamics in a paleolimnological perspective including lack of an appropriate temporal resolution and ecosystem feedback mechanisms. Combining paleoecology with contemporary studies can help clarify the scale of regime shifts and to distinguish patterns in ecosystem changes from natural variability.

Keywords Regime shift - Threshold · Alternative stable states $\cdot$ Climate change $\cdot$ Ecosystem dynamics

\section{Introduction}

Much of the research on regime shifts in the geological literature has had a paleoclimatic emphasis and has 
assumed that abrupt ecological change is evidence of abrupt climate change (Williams et al. 2011). Yet, not all abrupt ecological changes stem from abrupt climate change. The theoretical model of abrupt ecosystem change in response to a small and/or a continuous change in forcing has been around for about 40 years (Holling 1973; Noy-Meir 1975; May 1977). Although the terminology is varied (tipping points, regime shifts, critical transitions, bifurcations, etc.), the underlying theory suggests that ecosystems are complex and governed by a mixture of external drivers, positive and negative feedback loops and fast and slow processes. As a result, they can be resilient when subjected to an external forcing, such as climate change or enhanced nutrient loading, until an internal threshold is passed, resulting in a large and abrupt shift in ecosystem state (Scheffer et al. 2001b; Scheffer and Carpenter 2003; Folke et al. 2004; Andersen et al. 2009; Williams et al. 2011).

In this synthesis we investigate regime shifts in paleolimnological records and characterize them based on a framework described in Andersen et al. (2009), while also exploring the likely physical processes driving the shift. Although varied physical processes interact, such that there may not be a single driver of any observed change, this framework may elucidate the relationship between driver and regime shift dynamics and the associated imprint of a regime shift in the sediment record. When detected, past regime shifts offer rich opportunities to understand ecosystem responses to climate changes and the natural state and variability of ecosystems undergoing restoration efforts.

\section{Framework}

The terminology regarding regime shifts and regime shift theory has varied, and there is still no clear consensus on definitions and terminology. For the purpose of this paper, the significant terms are defined as follows:

A regime shift is a major ecosystem reconfiguration (in system structure, function and feedbacks) that is abrupt (occurring at rates that are rapid relative to background rates of change) and persistent (Folke et al. 2004; Lees et al. 2006; Andersen et al. 2009; Williams et al. 2011). It typically occurs at several trophic levels, affecting many of the ecosystem's state variables (Andersen et al. 2009; Crépin et al. 2012).

A threshold/tipping point is the point at which this abrupt change occurs, the place (in time) where a small change in driver can produce large responses in the ecosystem, and where a different set of system feedbacks become dominant (Dodds et al. 2010, Crépin et al. 2012). The existence of a threshold is key for demonstrating bistability or hysteresis according to Andersen et al. (2009). The existence of a threshold does not, however, always entail a regime shift; the state crossed into might not be persistent (Dodds et al. 2010).

Andersen et al. (2009) describe three scenarios for, or types of, regime shifts that we use as the base of our characterization (Fig. 1):

Type I "Smooth" pressure-status relationships, where an abrupt shift in the driver (e.g. climate change or nutrient input) is directly mediated to the ecosystem state.

Type II Threshold-like state responses, where an ecosystem undergoes a regime shift only after the driver exceeds a threshold; the relationship between the forcing and the response variables is non-linear.

Type III Bistable systems, which exhibit hysteresis behavior with two alternative regimes during increasing and decreasing modes of the driver.

The smooth and threshold-like changes (Type I and II) are reversible along the same trajectory when the driver or forcing variable is reversed, whereas in a bistable system with hysteresis, the critical threshold for a shift from regime 1 to 2 differs from the critical threshold for a return shift from 2 to 1 , because the different regimes have different sets of stabilizing feedbacks. As a consequence, regime shifts in bistable systems may be very difficult, or even impossible, to reverse (Crépin et al. 2012).

Because ecosystems are complex, the threshold at which a regime shift occurs, as well as the degree of reversibility, depends on the resilience or the strength of the feedback mechanisms maintaining the current state. This is usually determined by multiple factors, such as the composition of the biological community, lake depth and morphometry. Therefore ecosystem responses to the same forcing will differ among different systems and might also change over time within the same system: the same lake may display 
(A) Type I, driver threshold

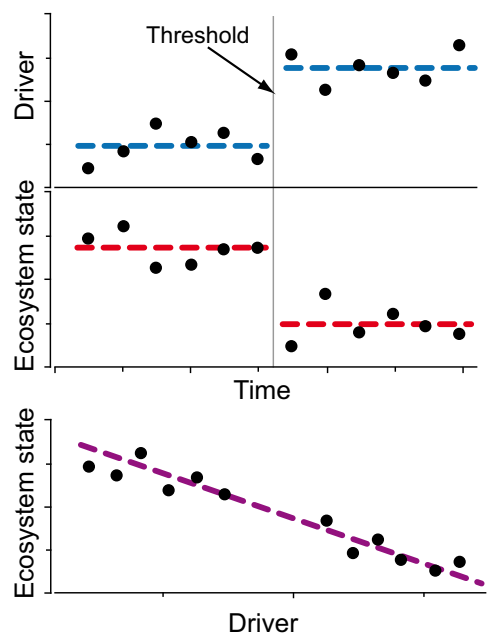

(B) Type II, state threshold
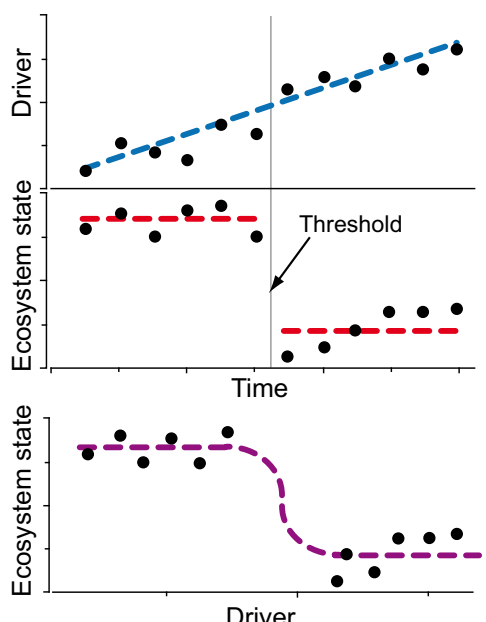

(C) Type III, driver-state hysteresis
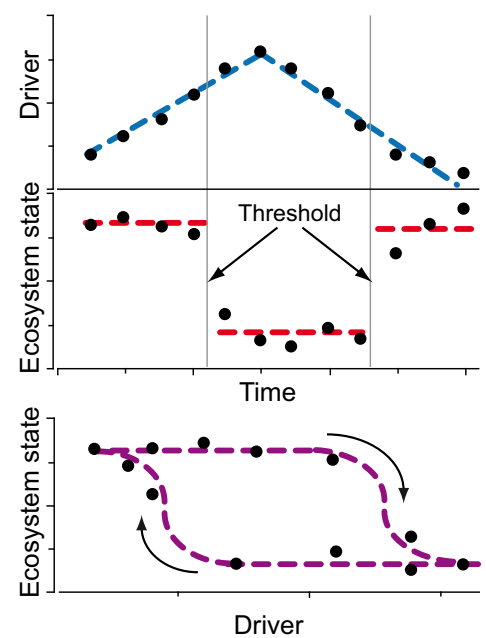

Fig. 1 Three types of regime shifts. The two top rows show time series of driver (e.g. nutrient input) and ecosystem state (e.g. macrophyte cover), and the lower row shows the relationship between driver and ecosystem state. Grey vertical lines represent regime shifts. a Type I: smooth pressure-status relationships; the regime shift in the driver is linearly mediated to the ecosystem state. b Type II: threshold-like state responses; regime shift in ecosystem occurs after driver exceeds a

linear or hysteretic responses depending on local conditions (Crépin et al. 2012). It is also possible that, during the time spent in one state, changes in forcing (for example $\mathrm{CO}_{2}$ concentration, temperature, wind patterns, lake infilling) may preclude the system from returning to previous conditions (Duarte et al. 2009).

While lakes are outstanding sentinels of environmental and climate change (Battarbee 2000; Williamson et al. 2009; Adrian et al. 2009; Leavitt et al. 2009), climate change impacts are often complex and multi-faceted, because the climatic signal is filtered through both catchment and in-lake processes. Thus, the structure and function of lake ecosystems is determined by complex interactions between climate change, humans, in-lake processes, lake ontogeny and catchment features (geology, soils, vegetation). Each of these variables varies in time and space and may have considerable influence on biological structure, as well as act as information filters, thereby altering climate effects on lakes (Schindler et al. 2001; Anderson et al. 2004; Leavitt et al. 2009; Fritz and Anderson 2013). We have identified three main driver pathways leading to regime shifts: (1) climate threshold. c Type III: bistable systems with hysteresis; when the driver is slowly increased and then decreased again the ecosystem jumps between two alternative states due to the hysteresis loop linking state and forcing; different ecosystem states can exist under the same conditions and in order for the system to change back to the "original" state the driver must exceed a second critical threshold, lower than the first. Redrawn from Andersen et al. (2009)

(including ice cover, precipitation, mixing and stratification, and catchment vegetation), (2) lake ontogeny (long-term changes in the lake or catchment associated with successional processes), and (3) anthropogenic forcing (including deforestation, pollution and eutrophication) (Table 1).

In the following, we will investigate the nature of lake responses according to the criteria used to classify three types of regime shifts described in Andersen et al. (2009) while also considering these different driver pathways. The conceptual framework provided by Andersen et al. (2009) may not recognize other possible types of regime shifts including those with slow, smooth variable rate transition (Seekell et al. 2013; Hughes et al. 2013). We focus our analysis on recent studies that infer ecosystem changes from sedimentary diatom assemblages. The 22 examples are summarized in Table 1 . Of the 34 papers included in this review, only nine specifically use the term "regime shift". The duration of the regime shift and identification of the main drivers are either described in the paper or estimated from the data presented in the individual studies. 
Table 1 Summary of studies included in this paper sorted by main driver

\begin{tabular}{|c|c|c|c|c|c|c|}
\hline No. & Main driver & $\begin{array}{l}\text { Regime } \\
\text { shift type }\end{array}$ & $\begin{array}{l}\text { Time of shift } \\
\text { (cal. yr b2 k) }\end{array}$ & $\begin{array}{l}\text { Duration of } \\
\text { shift (years) }\end{array}$ & $\begin{array}{l}\text { Duration of driver } \\
\text { change (years) }\end{array}$ & Main reference \\
\hline 1 & Climate: ice cover & I & 8250 & c. 25 & c. 25 & Anderson et al. (2008) \\
\hline 2 & Climate: ice cover & II & 5850,4150 & $300-400^{\mathrm{a}}$ & $3000-4000$ & Rouillard et al. (2012) \\
\hline 3 & Climate: ice cover & II & 1450 & c. 200 & c. 500 & Mackay et al. (2012) \\
\hline 4 & Climate: ice cover & II & 150 & c. $20-50$ & c. 200 & $\begin{array}{l}\text { Rühland et al. (2008), } \\
\text { Smol et al. (2005) }\end{array}$ \\
\hline 5 & Climate: precipitation & $\mathrm{I}$ & 8090 & $5-10$ & c. $2-5$ & $\begin{array}{l}\text { Randsalu-Wendrup } \\
\text { et al. (2012) }\end{array}$ \\
\hline 6 & Climate: precipitation & II & 70 & 5 & $10-20$ & Stone and Fritz (2004) \\
\hline 7 & Climate: precipitation & II & 1050 & $30-50$ & $200-300$ & Reuss et al. (2013) \\
\hline 8 & $\begin{array}{l}\text { Climate: mixing and } \\
\text { stratification }\end{array}$ & II & 7900 & $5-10$ & $200-300$ & $\begin{array}{l}\text { Randsalu-Wendrup } \\
\text { et al. (2012) }\end{array}$ \\
\hline 9 & $\begin{array}{l}\text { Climate: mixing and } \\
\text { stratification }\end{array}$ & II & 850 & $20-30$ & c. 500 & Bracht et al. (2008) \\
\hline 10 & $\begin{array}{l}\text { Climate: catchment } \\
\text { vegetation }\end{array}$ & II & 3050 & $100-200^{\mathrm{a}}$ & $300-500$ & Pienitz et al. (1999) \\
\hline 11 & $\begin{array}{l}\text { Climate: catchment } \\
\text { vegetation }\end{array}$ & II & 1800 & c. 200 & c. 1500 & Reuss et al. (2010) \\
\hline 12 & $\begin{array}{l}\text { Lake ontogenty }+ \text { ice cover } \\
\text { etc. }\end{array}$ & II & 6850 & 250 & $\begin{array}{l}\text { c. } 2000 \text { (alkalinity), } \\
\text { c. } 500 \text { (climate) }\end{array}$ & Paul et al. (2010) \\
\hline 13 & $\begin{array}{l}\text { Lake } \\
\text { ontogeny }+ \text { precipitation, } \\
\text { ice cover }\end{array}$ & II & 1050 & c. $200-300$ & c. 7000 & McGowan et al. (2003) \\
\hline 14 & Anthropogenic: deforestation & $\mathrm{I}$ & 2480 & c. $150^{\mathrm{a}}$ & c. 150 & Bradshaw et al. (2005) \\
\hline 15 & Anthropogenic: pollution & III & 35 & c. 5 & c. 5 & Sayer et al. (2006) \\
\hline 16 & $\begin{array}{l}\text { Anthropogenic: } \\
\text { eutrophication }\end{array}$ & III & 35 & $10-20^{\mathrm{a}}$ & $100-200$ & $\begin{array}{l}\text { Rasmussen and } \\
\text { Anderson (2005) }\end{array}$ \\
\hline 17 & $\begin{array}{l}\text { Anthropogenic: } \\
\text { eutrophication, lake level } \\
\text { changes }\end{array}$ & III & 50 & $1-4$ & c. 30 & Hobbs et al. (2012) \\
\hline
\end{tabular}

Duration of regime shift and duration of driver change has been estimated from data presented in the individual studies

a Temporal resolution of record constrains timing of regime shift

\section{Type I: Smooth regime shift}

Because of the often inherently slow forcing of climate (slow in comparison with the life cycles of organisms in limnological ecosystems), examples of smooth pressure regime shifts are not very abundant in the paleolimnological literature. The threshold is present in the forcing variable (Fig. 1a), and relatively few studies have examined how these climatic thresholds affect ecosystems. One issue in identifying an ecological response to a threshold in the driver is the potential for smoothing of the signal in the paleolimnological records and inherent uncertainties in chronological control, although these problems are mitigated in sites with varved sediments and good chronologies. For example, in a varved lake in midcentral Sweden, an abrupt change in precipitation associated with the abrupt cooling of the 8.2-ka event in the North Atlantic-region led to increased erosion in the catchment, an abrupt increase in nutrients entering the lake, and a shift within the lake to higher primary production, with a doubling of diatom accumulation rates over a period of 5-10 years (Randsalu-Wendrup et al. 2012; Table 1, no. 5). Similarly, but on a different scale, a cold, dry event approximately 8200 years ago led to prolonged ice cover in a lake 


\section{TYPE I - smooth regime shift}

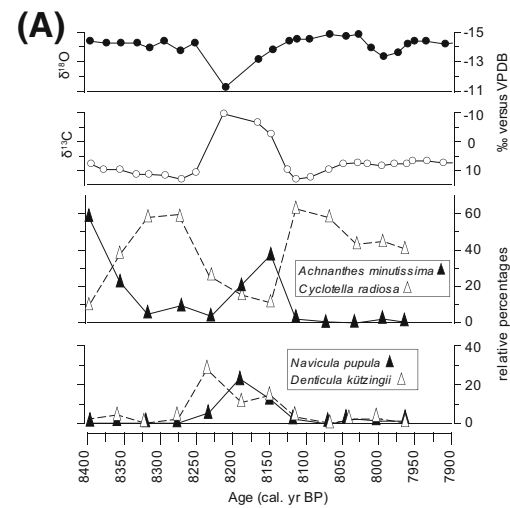

(B)

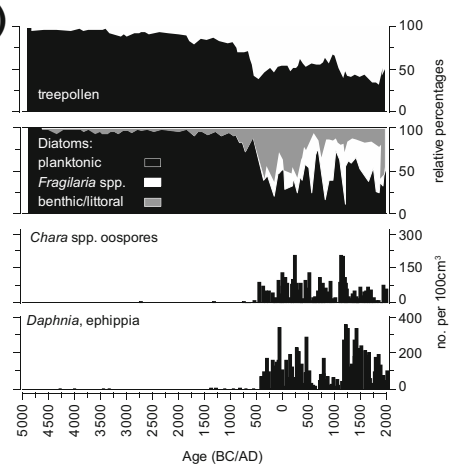

TYPE II - threshold response

(C)

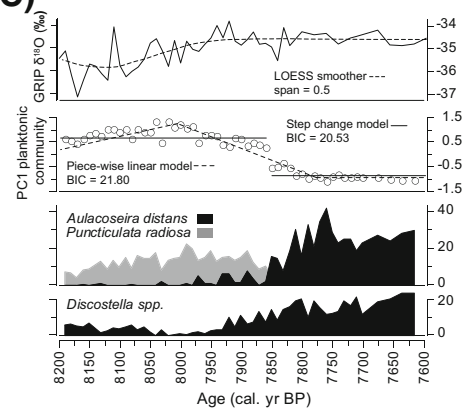

(D)

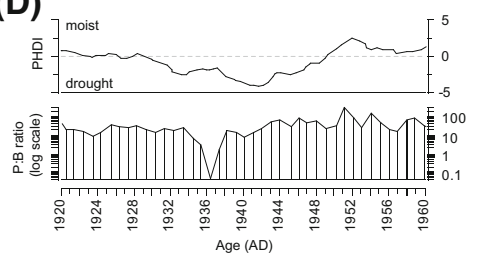

TYPE III - hysteresis response

(E)

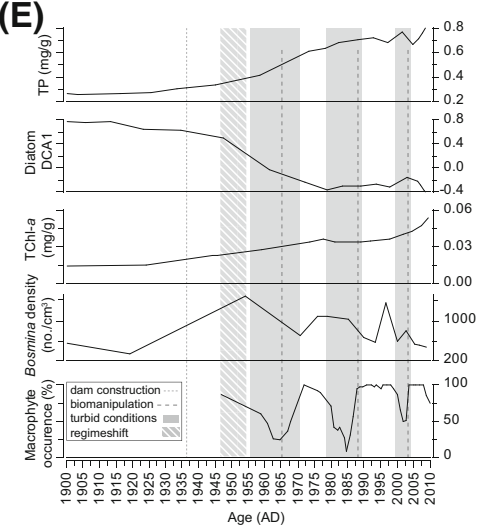

(F)

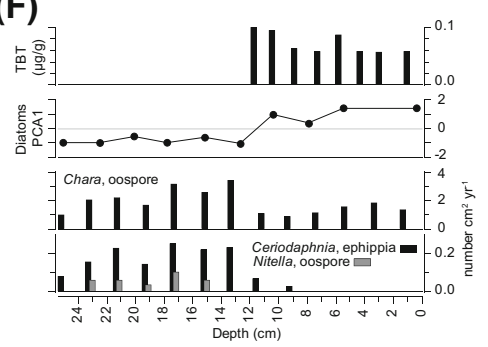

Fig. 2 Examples of different types of regime shifts from the literature. Type I, smooth regime shift: a profiles of key diatom species, $\delta^{18} \mathrm{O}$ and $\delta^{13} \mathrm{C}$ isotope records redrawn from Anderson et al. (2008). The increase in $\delta^{18} \mathrm{O}$ indicates increased aridity, while the coincidental reduction in $\delta^{13} \mathrm{C}$ reflects a reduction in productivity (Anderson et al. 2008). Simultaneous with the climate changes recorded by the isotope record is a significant decrease in planktonic Cyclotella radiosa (Grunow) Lemmermann 1900, and a corresponding increase in periphytic Achnanthes minutissima Kützing 1833, Navicula pupula Kützing 1844 and Denticula kuetzingii Grunow 1862, b summary proxy data describing the development of Dallund $S \varnothing$ and the landscape surrounding the lake redrawn from Bradshaw et al. (2005). At c. $500 \mathrm{BC}$ there is an abrupt decrease in the amount of tree pollen, accompanied by decreased proportions of planktonic diatoms and the appearance and expansion of charophyte vegetation and pelagic Daphnia spp. Type II, threshold-like regime shift: c $\delta^{18} \mathrm{O}$ record from the GRIP ice core, first principle component of the planktonic community and time series of key diatom species redrawn from Randsalu-Wendrup et al. (2012). PCA1 of the planktonic community was analysed for change-points over time using a combination of abrupt step

in southwest Greenland (Anderson et al. 2008; Table 1, no. 1; Fig. 2a). A resulting reduction in lake turbulence and decreased catchment weathering and nutrient inputs led to a major reduction in lake changes and piece-wise linear regressions (Randsalu-Wendrup et al. 2012). The optimal change-point model (assessed by the lowest BIC) is shown with solid lines, and the alternative less suitable model with dashed line. d 5-year running average of monthly regional moisture as measured by the Palmer hydrologic drought index (PHDI) and the annual record of planktic to benthic diatom ratio (log-scale) at Foy Lake. Redrawn from Stone and Fritz (2004). A pronounced increase in benthic diatoms occurred in the mid-1930s, simultaneous with a long period of regional drought. Type III, hysteresis-like regime shift: e Proxies of lake trophic status (TP), diatom assemblage turnover (Diatom DCA1), primary production (TChl- $a$ ) and Bosmina remains over the last 110 years, and submerged aquatic plant survey data since 1947 from Lake Christina. Redrawn from Hobbs et al. (2012). f TBT profile, first principle component of diatom community, fluxes of Chara and Nitella oospores and remains of zooplankton Ceriodaphnia from Hickling Broad, redrawn from Sayer et al. (2006). With the appearance of TBT in the lake, there is a loss of submerged vegetation and zooplankton as well as a shift in diatom community composition

productivity and an abrupt shift from a planktonic to a periphytic algal community, similar to the pattern observed in many contemporary Arctic and highaltitude lakes (Lotter and Bigler 2000). The regime 
shift took place over approximately 25 years, and the system remained in the cold state for 50 years before returning to its former state, at approximately the same rate as the climate change.

Rapid threshold-like changes in drivers are often anthropogenic in nature. In Danish lake Dallund Sø (synthesized in Bradshaw et al. 2005; Table 1, no. 14) major, rapid deforestation around $500 \mathrm{BC}$ led to enhanced catchment erosion and increased nutrient input into the lake, as well as lake infilling and shallowing. The changes in water depth and in-lake nutrient concentration led to extreme changes in the aquatic environment: an expansion of submerged vegetation, higher in-lake productivity and associated changes in the diatom flora (Fig. 2b). The lake, which was originally an oligotrophic system, changed to a eutrophic system. The new regime appeared to be more sensitive to external forcing from the catchment based on a change in the diatom data from an early interval of relative stability to a subsequent period during the Iron Age (500 BC-AD 1050) of marked fluctuations in the ratio of planktonic/nonplanktonic diatoms, which continued to the modern day. This variability may, to some extent, also be a function of intensified anthropogenic impact over time.

\section{Type II: Threshold response}

In tipping-point regime shifts, the change in driver does not affect the ecosystem response variable until a critical ecosystem threshold is reached, at which point the system state changes rapidly (Andersen et al. 2009; Fig. 1b). The forcing is progressive and gradual, although often overlaid by higher-frequency variability, and abrupt ecological change is driven by internal dynamics in the ecological systems. Since the internal dynamics are strongly governed by site-specific factors, such as catchment characteristics, lake depth, biological competition, and disturbance, local responses to a common regional forcing can be quite heterogeneous, i.e. different lakes react differently to the same forcing (Williams et al. 2011).

\section{Climate}

Direct climate impacts on ice cover can cause regime shifts. Long periods of ice-cover, promoted by cool temperatures, can inhibit primary production and habitat availability, whereas decreased ice cover duration may increase the length of growing season and the duration of water column stratification (Mackay et al. 2012; Catalan et al. 2013). Ice cover responds in a non-linear fashion to small changes in temperature (Weyhenmeyer et al. 2004), thus relatively subtle temperature changes can cause dramatic changes in lake state.

Rapid ecological reorganizations, which have been attributed to recent climate warming mediated through changing ice-cover dynamics, are presently occurring in lakes throughout the Northern Hemisphere (Smol et al. 2005; Smol and Douglas 2007; Rühland et al. 2008; Rouillard et al. 2012; Table 1, no. 4). Although these regime shifts are manifested at several trophic levels (Smol et al. 2005), the shifts have been described mainly from changes in the species composition of diatom communities and are characterized by increases in small planktonic diatoms, such as $C y$ clotella species, and a compensatory decrease in small periphytic (often Fragilaria) species. The changes suggest shorter periods of ice-cover, longer growing seasons and increased thermal stratification (Rühland et al. 2008). Rühland et al. (2008) reject nutrient dynamics as a contributing mechanism in the shifts, while Saros et al. (2012) argue that interplay between light, thermal stratification and nitrogen availability is driving the diatom changes. Nonetheless, given the inherently non-linear responses of ice cover to climate change (Weyhenmeyer et al. 2004), we consider it likely that these changes are threshold-like.

A similar ecological regime shift connected to climate warming, although earlier in time, has been described from an alpine lake in southern Siberia during the Medieval Climate Anomaly (Mackay et al. 2012; Table 1, no. 3). A major shift in diatom species composition at $1400 \mathrm{cal}$. yr BP is characterized by a marked decline in fragilarioid taxa, concomitant with an increase in species diversity as a result of greater habitat availability due to shorter ice-cover duration. An additional contributor to ecosystem change at this site is a lowering of lake water $\mathrm{pH}$ as a result of permafrost melting and increased DOC export from forest soils (Mackay et al. 2012).

Lakewater $\mathrm{pH}$ has been proposed as an important driver of diatom assemblage changes in poorly buffered Arctic and Alpine lakes, with warm intervals resulting in higher $\mathrm{pH}$ values due to enhanced loss of $\mathrm{CO}_{2}$ to the atmosphere and greater utilization of 
limnetic $\mathrm{CO}_{2}$ by algal photosynthesis, compared with cooler periods with longer ice-cover (Michelutti et al. 2007; Rouillard et al. 2012; Wilson et al. 2012; Fritz and Anderson 2013). Two poorly buffered lakes in the high Arctic of Canada show regime shifts, with a shift in diatom dominance from small benthic Fragilaria taxa to a more diverse but less productive assemblage of small benthic and periphytic species, including slightly acidophilous Achnanthes and Navicula taxa (Rouillard et al. 2012; Table 1, no. 2). The dynamics behind the shifts are connected to the neoglacial cooling caused by decreasing summer insolation from the mid- to late Holocene, and the associated lengthening of ice cover and decreased lakewater $\mathrm{pH}$ (Rouillard et al. 2012). The shifts, however, occur with a lag of approximately 1200 -years relative to the cooling trend as a result of carbonate-rich glacial tills that buffered the lakes. This emphasizes the importance of lake catchment characteristics in determining lake response to direct climate change.

In addition to influencing ice-cover, changes in temperature and associated changes in wind patterns can influence lake thermal stratification and mixing regimes directly (Panizzo et al. 2008; Medeiros et al. 2012). This, in turn, has a strong influence on the competitive abilities of phytoplankton either by directly controlling their buoyancy or indirectly controlling the availability of nutrients (Battarbee 2000). A regional change in climate in the Rocky Mountains at the onset of the Little Ice Age caused ecosystem changes in Crevice Lake, Montana, where changes in planktonic diatom species composition were driven by changes in the length and stability of summer stratification relative to the length of isothermy following ice melt (Bracht et al. 2008; Table 1, no. 9). At $c$. 800 cal. yr BP a large and abrupt increase in Stephanodiscus spp. occurred, likely caused by a transition to long, cool springs with extended periods of mixing. This occurred at the middle of the global cooling trend between the Medieval Climate Anomaly (1500-1000 cal. yr BP) and the Little Ice Age (500-100 cal. yr BP) (Marcott et al. 2013). BrachtFlyr and Fritz (2012) compare diatom records from four lakes in western Montana (including Crevice Lake), which display different responses at roughly the same time (800-600 cal. yr BP), emphasizing the importance of local ecosystem characteristics in mediating climate impacts on biological communities. The pattern in Crevice Lake is similar to that observed by Smol et al. (2005), Rühland et al. (2008) and others: a dominance of Cyclotella spp. associated with warmer conditions and enhanced stratification of the water column.

A similar diatom response occurred with the gradual climate warming after the cooling of the 8.2ka event in mid-central Sweden (Randsalu-Wendrup et al. 2012; Table 1, no. 8; Fig. 2c). The warming led to stable lake stratification, a shallower mixing depth, a shift to dominance of planktonic species and an abrupt shift within the planktonic community over 5-10 years at c. 7850 cal. yr BP (Randsalu-Wendrup et al. 2012).

Precipitation variability also influences lake ecosystems directly (Leavitt et al. 2009), and changes in the balance between precipitation and evaporation influence salinity and lake level, which, in turn, can drive regime shifts in lake ecosystems (Fritz et al. 2000; Laird et al. 2003). A regime shift from a dilute, oligotrophic lake to a lake with strong seasonal chemical stratification, hypolimnic anoxia and a large phototrophic bacterial production at $c .900 \mathrm{cal}$. yr BP was observed in Lake SS86 in western Greenland (Reuss et al. 2013; Table 1, no. 7). The regime shift was marked by a shift from algal pigments to near complete dominance of pigments specific to green sulphur bacteria, which require photic zone anoxia to grow. The shift occurred in the latter part of the Medieval Climate Anomaly, and the authors propose that reduced precipitation caused lake-level lowering. Due to its morphometry, when the lake level dropped below the outlet level, the lake became a closed basin. This allowed for a different set of feedback mechanisms to dominate the lake, and stratification rather than precipitation became the strongest influence on ecosystem state. The climate change during the Medieval Climate Anomaly was gradual, as likely was the lake level lowering, but as the lake reached a threshold (in this case a lowering beneath an actual, physical threshold) a rapid regime shift occurred.

Lake morphometry also plays a major role in controlling regime shifts in Foy Lake in the North American Rocky Mountains, where large and rapid spikes in benthic diatom abundance during the last 800 years were likely caused by relatively small changes in lake level that produced large changes in the amount of habitat available for benthic diatoms (Stone and Fritz 2004; Stevens et al. 2006; Table 1, no. 6). The Foy Lake record shows regime shifts that result 
from an interaction of climate change and lake morphology, with climate causing lake level lowering through altered precipitation-evaporation balance, but morphology determining the diatom response to these (sometimes small) climatic shifts.

In forested catchments, or catchments close to the tree line, changes in vegetation affect the supply of DOC and nutrients to lakes, influencing aquatic communities and biological productivity (Anderson et al. 2008; Mackay et al. 2012). Direct influence of treeline dynamics on lake ecosystems is shown by Pienitz et al. (1999; Table 1, no. 10), who reconstructed an abrupt shift in diatom composition and a rapid decrease in lake-water DOC content following the retreat of spruce (Picea abies (L.) H. Karst.) from the catchment of a subarctic Canadian lake (Queen's Lake). The sensitivity of the lake was influenced by its dilute nature (Pienitz et al. 1999). Several other studies have shown abrupt changes in geochemical proxies in response to treeline retreat or advance, whereas biological proxies often show more diverse or delayed responses. Reuss et al. (2010; Table 1, no. 11) describe an abrupt ecological shift in a subarctic lake at treeline in northern Sweden, at $c .1750$ cal. yr BP, when a drop in the $\mathrm{C} / \mathrm{N}$ ratio, significant changes in the chironomid communities and a shift in the phototrophic community from diatom dominance to increased influence of chlorophytes suggest expansion of aquatic mosses. This is connected to a period of continued late-Holocene cooling and is followed by a shift in diatom composition to benthic dominance around $1000 \mathrm{cal}$. yr BP. General treeline retreat in the area started around $3200 \mathrm{cal}$. yr BP, with resulting soil destabilization and increased wind exposure of the lake. The shift at $1750 \mathrm{cal}$. yr BP is likely a threshold response of the aquatic ecosystem to the treeline retreat, following a long period of gradual changes in physical and chemical properties of the lake that altered habitat availability. Other studies have also shown major limnological change associated with climate-driven impacts mediated through catchment and vegetation dynamics (Jones et al. 2011), but many show gradual changes rather than regime shifts.

\section{Lake ontogeny}

Lakes inherently change as they age and, as newly formed landscapes evolve, physical and biological changes occur that are collectively known as primary succession. The ontogenetic processes may proceed in a non-linear manner (Engstrom et al. 2000), and the constantly shifting baselines mean that a similar external forcing may influence the same lake in a contrasting way depending on the stage of lake development. For example, Braya $S \varnothing$, a closed-basin oligosaline lake in West Greenland, has displayed several abrupt shifts in lake salinity (as conductivity inferred from diatoms) and lake level (inferred from radiocarbon dating of lake terraces) throughout the Holocene (McGowan et al. 2003, Table 1, no. 13; Fritz 2008; Aebly and Fritz 2009). McGowan et al. (2008) showed that lake response changed as the lake aged; a slow accumulation of salts (increasing conductivity) through time eventually allowed a threshold to be crossed at $c .1000$ years BP, and after this point the lake alternated between meromixis and fully mixed states. Meromixis involves the isolation of denser saline bottom waters from the upper fresher mixed layer, and the availability of salts is a necessary antecedent condition. Within the latest 1000 years of the Braya $S \varnothing$ record, the cessation of the meromictic state resulted in larger fluctuations in salinity than would occur in a dimictic or monomictic lake, because of the entrainment of the highly saline bottom layer into surface waters (McGowan et al. 2003). The resultant abrupt shifts in mixing status resulted in very different algal communities, with cyanobacteria dominating during mixed periods and purple sulphur bacteria during periods of meromixis (Anderson et al. 2004). Thus, in some lake states a relatively small change in the precipitation-evaporation balance can produce a disproportionate response in the physico-chemical properties of the lake, causing reorganization of the community structure and a regime shift.

Similarly, reconstructions from a small low Arctic lake $200 \mathrm{~km}$ north of the forest-tundra ecotone in mainland Nunavut, Canada (Paul et al. 2010; Table 1, no. 12) also demonstrate the importance of natural lake development and lake age in determining lake response to climate forcing. A rapid and almost complete diatom species turnover occurred around $6800 \mathrm{cal}$. yr BP in response to climate warming at the onset of the Holocene Thermal Maximum (Rühland 2001; Smol et al. 2005, Mackay et al. 2012), with an associated increase in the open-water period and longer growing seasons. However, the authors argue that the shift is also likely attributable to a natural 
long-term loss of alkalinity in the lake because of a transition to a less alkaline diatom assemblage. Paul et al. (2010) argue that the abruptness of the shift suggests that the combination of long-term alkalinity loss, driven by the depletion of base cations from the developing soils and the increased contribution of organic acids from surrounding vegetation, together with factors mediated by warmer climate (i.e. shorter ice-cover duration, longer growing season) led to the crossing of a critical threshold and the observed regime shift.

\section{Type III: Hysteresis response}

In bistable systems with hysteresis, the trajectory of the response variable will be different for increasing versus decreasing modes of the driver (Andersen et al. 2009; Collie et al. 2004). A single transition from one state to another is the same for the non-linear threshold and the hysteresis responses (Fig. 1b, c). Demonstrating hysteresis requires data where the driver is both increasing and decreasing, giving rise to shifts between states occurring at different thresholds (Collie et al. 2004, Wang et al. 2012). Thus, it may be difficult to demonstrate that a discontinuous regime shift has taken place: in modern environments stresses are often continuously increasing (Wang et al. 2012), and in paleolimnological studies it is often difficult to evaluate whether different states exist under the same conditions (i.e. alternative stable states), partly because the non-stationary baseline associated with lake ontogeny, as described above, changes the driverecosystem response independent of the direction of change in the driver.

Bistable systems with hysteresis are often described as "alternative stable states" in the limnological literature, and shallow lakes are commonly used as examples, because they, if simplified, commonly alternate between two states: one characterized by dominance of aquatic plants and clear water and the other by phytoplankton dominance and turbid water (Scheffer et al. 1993). Often, however, changes between states may occur gradually or cyclically or evolve via a transition state (Hargeby et al. 2007; Scheffer and van Nes 2007; Sayer et al. 2010b).

Shallow lakes as bistable systems with hysteresis are especially well studied in association with anthropogenic eutrophication (Jeppesen et al. 1998;
McGowan et al. 2005; Scheffer and van Nes 2007; Scheffer and Jeppesen 2007; Hargeby et al. 2007; Zimmer et al. 2009, Sayer et al. 2010b). Regime shifts are often the result of multiple stressors, and, in many cases, the changes in forcing variable have exposed the ecosystems to conditions beyond the range of natural variability (Collie et al. 2004). Lake Christina in Minnesota, USA, showed a dramatic regime shift in c. 1950 from a stable clear-water, macrophyte-dominated state to a managed period with turbid phytoplankton-dominated states (Hobbs et al. 2012; Theissen et al. 2012; Table 1, no. 17; Fig. 2e). The regime shift was a consequence of multiple stressors working over an approximately 30 year period: eutrophication beginning in the 1930s and 1940s that made the lake more unstable and susceptible to a regime shift and increased annual rainfall which, along with the construction of a dam on the main outlet of the lake, increased water levels (Hobbs et al. 2012). After the shift into turbid conditions, the lake has been managed through fish removal three times (1965, 1987 and 2003). These manipulations have increased water clarity and the extent of submerged aquatic plants, but the improvements were temporary and persisted only approximately 10 years following 1965 and 1987 and five years after 2003. The biomanipulation seemed to move the ecosystem back and forth along a turbidity gradient, but ultimately a return to a clear-water ecosystem is not possible without the reduction of nutrients to limit algal production (Hobbs et al. 2012); thus the lake shows hysteresis-like behavior. The variable stability of alternative states was also evident in the shallow Danish Gundsømagle S $\emptyset$, which, after a smooth regime shift around $1300 \mathrm{BC}$ was mesoeutrophic, with an extensive and diverse aquatic flora for more than 3000 years, despite extensive agriculture and climate variability (Rasmussen and Anderson 2005; Table 1, no. 16). Around 1960, however, the submerged vegetation collapsed, and floating-leaved Nymphaceae vegetation expanded, probably as a result of sustained anthropogenic stress with unprecedented levels of erosional input and external nutrient loading (Rasmussen and Anderson 2005).

Other anthropogenic stressors can also perturb lake ecosystems and cause changes in concert with eutrophication: one example is from the Norfolk Broads, UK, where the introduction of toxic tributyl tin (TBT) as an antifouling paint on boats in the lakes in the 1960s caused regime shifts, with a dramatic loss 
of submerged vegetation, the replacement of macrophytes by phytoplankton and a shift in associated diverse animal communities (Sayer et al. 2006; Table 1, no. 15; Fig. 2f). The resilience of the system was already low due to eutrophication, fish kills and increased salinity, but the proximate driver of the shift was a reduction in grazing invertebrates, particularly molluscs and zooplankton, by TBT (to which it is highly toxic). The breakdown of a feedback loop that had reinforced plant dominance led to dense growths of periphytic and planktonic algae and a rapid loss of aquatic vegetation (Sayer et al. 2006).

As stated earlier and illustrated in the examples above, most of these types of regime shifts are studied in shallow lake systems affected by anthropogenic impact (mainly eutrophication). The role of climate in triggering switches between alternative states is controversial (Jeppesen et al. 2003), but it has been suggested that changes in temperature can alter water clarity by influencing zooplankton grazing potential (Scheffer et al. 2001a; Jeppesen et al. 2003) and that physical disturbance from hurricanes (Bachmann et al. 1999; Lowe et al. 2001) or water level change (Blindow 1992; Blindow et al. 1993) can initiate state changes.

\section{Perspectives}

It is well established that regime shifts in lake ecosystems can occur as a result of both abrupt and continuous climate change, and that regime shifts may leave an imprint in paleolimnological records, allowing us to investigate and better understand patterns and processes governing abrupt ecological changes on a geological timescale. In our literature survey we examined the relations between the duration of change in driver and the duration of the regime shift (Fig. 3). In keeping with our conceptual model (Fig. 1), type I regime shifts fall on the 1:1 line with forcing and response variables acting on similar timescales, while regime shifts of type II and III fall above the line with regime shifts acting on a shorter time scale than changes in the drivers. The exception is Sayer et al.'s (2006; Table 1, no. 15) study of regime shifts caused by TBT, classified as type III but displaying type I-like behaviour with the regime shift from clear water to turbid conditions occurring as an immediate response to the change in driver (introduction of TBT). This

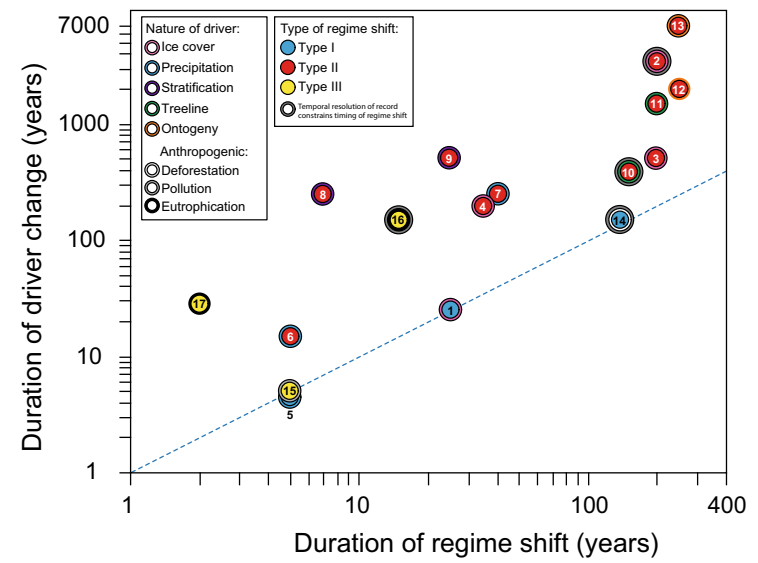

Fig. 3 Duration of regime shift plotted against duration of driver change. Numbers refer to reference numbers in Table 1. Dashed blue line is a 1:1 line showing regime shift duration equalling duration of driver change

discrepancy highlights the importance of driver selection when classifying regime shifts: because the multitude of drivers affecting lake ecosystems act on different timescales, the classification of ecosystem response to a changing driver depends on which driver is the focus of the investigation. The ecosystem described in Sayer et al. (2006) is influenced by slower drivers, such as eutrophication and increased salinity, which reduced the resilience of the system and made it more vulnerable to perturbations. The introduction of TBT becomes the proverbial straw breaking the camel's back, forcing the system into a turbid state, which is then maintained even when TBT inputs are reduced. Thus characterizing this transition as a type III regime shift is appropriate. Similarly, a focus on precipitation as the main driver of the regime shift described in Reuss et al. (2013) led to its classification as type II, but had we instead focused on lake characteristics (open or closed lake basin), the regime shift would be classified as type I, with a threshold crossed in the driver (basin becoming closed), which gave rise to an abrupt ecosystem change. In general, climate-related drivers and physical processes act on similar timescales, and we demonstrate that these drivers can give rise to regime shifts that can be classified as either smooth, threshold-like or bistable.

A common problem in working with paleolimnological records in general, and when investigating regime shifts in particular, is low temporal resolution. In some of the literature used in our analysis (Fig. 3), 
the temporal resolution of the record limits identification of the timing and rate of the regime shifts. In these examples, the regime shift occurs between two samples, but given a resolution of 150 (Bradshaw et al. 2005) or even 300-400 years (Rouillard et al. 2012) per sample, it is impossible to establish whether the shift has taken place over 100, 10 or even 1 year. However, in all of the examples the forcing is acting on even longer time scales (Table 1; Fig. 3), allowing identification of the general dynamics driving the shift, although the specifics are hidden in the time integration inherent in sediment records. Resolution is also an important factor when discussing terminology and definitions: a shift in ecosystem state is generally considered a regime shift if it is abrupt and persistent (Folke et al. 2004; Lees et al. 2006; Andersen et al. 2009; Williams et al. 2011). But what is persistent on a geological time scale? Anderson et al. (2008) describe a regime shift where the system stays in the new regime for 50 years before shifting back again. In the perspective of modern day monitoring data, this period is long, and the regime persistent, but in some of the other studies presented here, the shift might not be evident in the record due to low time resolution.

It is difficult to extrapolate ecosystem responses over space and time, because ecosystem responses to the same forcing mechanisms will differ among different systems and also change over time within the same system. In addition, the paleoclimate history at any one site is always imperfectly known, making it difficult to rule out the possibility that abrupt ecological changes observed at one site were in fact forced by an unknown but suddenly changing external driver (Williams et al. 2011). Using multiple records from the same region, however, can help overcome this problem. Bracht-Flyr and Fritz (2012) showed that at a regional scale external climate events can simultaneously force multiple local systems into new states, although the rate and characteristics of the changes vary among sites. Similarly, Smol et al. (2005), Rühland et al. (2008) and others showed the same patterns of change in response to climate warming across the northern hemisphere, although individual lakes responded in a site-specific manner. Thus, independent evidence of the nature of the forcing mechanism can be derived by regional replication from multiple sites, or indeed from other proxies at the same site.

One of the remaining challenges in understanding regime shifts and ecosystem dynamics in a paleolimnological perspective is that we lack the tools to thoroughly identify system feedback mechanisms. Sayer et al. (2010a), Battarbee and Bennion (2012) and Battarbee et al. (2012) argue that the solution to this is to combine contemporary ecology and paleolimnology. Linking the timescales of these approaches can allow us to disentangle the role of different forcings on lake ecosystems and to understand the mechanisms behind ecosystem responses to these forcings. The strength of paleolimnology in this setting is perhaps not only to look directly at individual changes, but to be able to use long sediment records to really understand the mean state of a lake ecosystem, identify natural variability of states and the degree of their persistence in relation to lake history, and to identify real departures from the mean state. This can improve contemporary studies where changes that we identify as regime shifts on one scale, might actually be part of the natural variability of the system: persistent for years or decades, but perhaps not longer.

Acknowledgments This work was supported by the Swedish Research Council (Vetenskapsrådet) and The Royal Physiographical Society in Lund (Kungliga Fysiografiska Sällskapet i Lund).

Open Access This article is distributed under the terms of the Creative Commons Attribution 4.0 International License (http:// creativecommons.org/licenses/by/4.0/), which permits unrestricted use, distribution, and reproduction in any medium, provided you give appropriate credit to the original author(s) and the source, provide a link to the Creative Commons license, and indicate if changes were made.

\section{References}

Adrian R, O'Reilly CM, Zagarese H, Baines SB, Hessen DO, Keller W, Livingstone DM, Sommaruga R, Straile D, Van Donk E, Weyhenmeyer G, Winder M (2009) Lakes as sentinels of climate change. Limnol Oceanogr 54:2283-2297

Aebly FA, Fritz SC (2009) Palaeohydrology of Kangerlussuaq (Søndre Strømfjord), West Greenland during the last $\sim 8000$ years. Holocene 19:91-104

Andersen T, Carstensen J, Hernandez-Garcia E, Duarte CM (2009) Ecological thresholds and regime shifts: approaches to identification. Trends Ecol Evol 24:49-57

Anderson N, Ryves DB, Grauert M, McGowan S (2004) Holocene paleolimnology of Greenland and the North Atlantic Island (North of 60 degrees N). In: Pienitz R, Douglas M, Smol JP (eds) Long-term environmental change in Arctic and Antarctic lakes, vol 8. Springer, Dordrecht, pp 319-347

Anderson NJ, Brodersen KP, Ryves DB, McGowan S, Johansson LS, Jeppesen E, Leng MJ (2008) Climate versus in- 
lake processes as controls on the development of community structure in a low-arctic lake (South-West greenland). Ecosystems 11:307-324

Bachmann RW, Hoyer MV, Canfield DE (1999) The restoration of Lake Apopka in relation to alternative stable states. Hydrobiologia 394:219-232

Battarbee RW (2000) Palaeolimnological approaches to climate change, with special regard to the biological record. Quat Sci Rev 19:107-124

Battarbee RW, Bennion H (2012) Using palaeolimnological and limnological data to reconstruct the recent history of European lake ecosystems: introduction. Freshw Biol 57:1979-1985

Battarbee RW, Anderson NJ, Bennion H, Simpson GL (2012) Combining limnological and palaeolimnological data to disentangle the effects of nutrient pollution and climate change on lake ecosystems: problems and potential. Freshw Biol 57:2091-2106

Blindow I (1992) Long- and short-term dynamics of submerged macrophytes in two shallow eutrophic lakes. Freshw Biol 28:15-27

Blindow I, Andersson G, Hargeby A, Johansson S (1993) Longterm patterns of alternative stable states in two shallow eutrophic lakes. Freshw Biol 30:159-167

Bracht B, Stone JR, Fritz SC (2008) A diatom record of late Holocene climate variation in the northern range of Yellowstone National Park, USA. Quat Intern 188:149-155

Bracht-Flyr B, Fritz SC (2012) Synchronous climatic change inferred from diatom records in four western Montana lakes in the U.S. Rocky Mountains. Quat Res 77:456-467

Bradshaw EG, Rasmussen P, Odgaard BV (2005) Mid-to lateHolocene land-use change and lake development at Dallund S $\varnothing$, Denmark: synthesis of multiproxy data, linking land and lake. Holocene 15:1152-1162

Catalan J, Pla-Rabés S, Wolfe AP, Smol JP, Rühland KM, Anderson NJ, Kopacek J, Stuchlík E, Schmidt R, Koinig KA, Camarero L, Flower RJ, Heiri O, Kamenik C, Korhola A, Leavitt PR, Psenner R, Renberg I (2013) Global change revealed by palaeolimnological records from remote lakes: a review. J Paleolimnol 49:513-535

Collie J, Richardson K, Steele J (2004) Regime shifts: can ecological theory illuminate the mechanisms? Prog Ocean 60:281-302

Crépin AS, Biggs R, Polasky S, Troell M (2012) Regime shifts and management. Ecol Econ 84:15-22

Dodds WK, Clements WH, Gido K, Hilderbrand RH, King RS (2010) Thresholds, breakpoints, and nonlinearity in freshwaters as related to management. J North Am Benthol Soc 29:988-997

Duarte CM, Conley DJ, Carstensen J, Sanchez-Camacho M (2009) Return to neverland: shifting baselines affect eutrophication restoration targets. Estuar Coasts 32:29-36

Engstrom D, Fritz S, Almendinger J, Juggins S (2000) Chemical and biological trends during lake evolution in recently deglaciated terrain. Nature 408:161-166

Folke C, Carpenter S, Walker B, Scheffer M, Elmqvist T, Gunderson L, Holling CS (2004) Regime shifts, resilience, and biodiversity in ecosystem management. Annu Rev Ecol Evol S 35:557-581

Fritz SC (2008) Deciphering climatic history from lake sediments. J Paleolimnol 39:5-16
Fritz SC, Anderson NJ (2013) The relative influences of climate and catchment processes on Holocene lake development in glaciated regions. J Paleolimnol 49:349-362

Fritz SC, Ito E, Yu Z, Laird KR, Engstrom DR (2000) Hydrologic variation in the northern Great Plains during the last two millennia. Quat Res 53:175-184

Hargeby A, Blindow I, Andersson G (2007) Long-term patterns of shifts between clear and turbid states in Lake Krankesjon and Lake Takern. Ecosystems 10:28-35

Hobbs WO, Hobbs JMR, LaFrançois T, Zimmer KD, Theissen KM, Edlund MB, Michelutti N, Butler MG, Hanson MA, Carlson TJ (2012) A 200-year perspective on alternative stable state theory and lake management from a biomanipulated shallow lake. Ecol Appl 22:1483-1496

Holling CS (1973) Resilience and stability of ecological systems. Annu Rev Ecol Syst 4:1-23

Hughes TP, Linares C, Dakos V, van de Leemput IA, van Nes EH (2013) Living dangerously on borrowed time during slow, unrecognized regime shifts. Trends Ecol Evol 28:149-155

Jeppesen E, Lauridsen TL, Kairesalo T, Perrow MR (1998) Impact of submerged macrophytes on fish-zooplankton interactions in lakes. In: Jeppesen E, Søndergaard M, Christoffersen K (eds) Ecological studies 131: the structuring role of submerged macrophytes in lakes. Springer, Dordrecht, pp 91-114

Jeppesen E, Søndergaard M, Jensen J (2003) Climatic warming and regime shifts in lake food webs - some comments. Limnol Oceanogr 48:1346-1349

Jones VJ, Solovieva N, Self AE, McGowan S, Rosén P, Salonen JS, Seppä H, Väliranta M, Parrott E, Brooks SJ (2011) The influence of Holocene tree-line advance and retreat on an arctic lake ecosystem: a multi-proxy study from Kharinei Lake, North Eastern European Russia. J Paleolimnol 46:123-137

Laird K, Cumming B, Wunsam S, Rusak JA, Oglesby RJ, Fritz SC, Leavitt PR (2003) Lake sediments record large-scale shifts in moisture regimes across the northern prairies of North America during the past two millennia. Proc Natl Acad Sci USA 100:2483-2488

Leavitt PR, Fritz SC, Anderson NJ, Baker PA, Blenckner T, Bunting L, Catalan J, Conely DJ, Hobbs WO, Jeppesen E, Korhola A, McGowan S, Rühland K, Rusak JA, Simpson GL, Solovieva N, Werne J (2009) Paleolimnological evidence of the effects on lakes of energy and mass transfer from climate and humans. Limnol Oceanogr 54:2330-2348

Lees K, Pitois S, Scott C, Frid C, Mackinson S (2006) Characterizing regime shifts in the marine environment. Fish Fish 7:104-127

Lotter A, Bigler C (2000) Do diatoms in the Swiss Alps reflect the length of ice-cover? Aquat Sci 62:125-141

Lowe EF, Battoe LE, Coveney MF, Schelske CL, Havens KE, Marzolf ER, Ramesh Reddy K (2001) The restoration of Lake Apopka in relation to alternative stable states: an alternative view to that of Bachmann et al. (1999). Hydrobiologia 448:11-18

Mackay AW, Bezrukova EV, Leng MJ, Meaney M, Nunes A, Piotrowska N, Self A, Shchetnikov A, Shilland E, Tarasov P, Wang L, White D (2012) Aquatic ecosystem responses to Holocene climate change and biome development in boreal, central Asia. Quat Sci Rev 41:119-131 
Marcott SA, Shakun JD, Clark PU, Mix AC (2013) A reconstruction of regional and global temperature for the past 11,300 years. Science 339:1198-1201

May RM (1977) Thresholds and breakpoints in ecosystems with a multiplicity of stable states. Nature 269:471-477

McGowan S, Ryves DB, Anderson NJ (2003) Holocene records of effective precipitation in West Greenland. Holocene 13:239-249

McGowan S, Leavitt P, Hall RI, Anderson NJ, Jeppesen E, Odgaard BV (2005) Controls of algal abundance and community composition during ecosystem state change. Ecology 86:2200-2211

McGowan S, Juhler RK, Anderson NJ (2008) Autotrophic response to lake age, conductivity and temperature in two West Greenland lakes. J Paleolimnol 39:301-317

Medeiros AS, Friel CE, Finkelstein SA, Quinlan R (2012) A high resolution multi-proxy record of pronounced recent environmental change at Baker Lake, Nunavut. J Paleolimnol 47:661-676

Michelutti N, Wolfe AP, Briner JP, Miller GH (2007) Climatically controlled chemical and biological development in Arctic lakes. J Geophys Res Biogeosci 112:G03002

Noy-Meir I (1975) Stability of grazing systems: an application of predator-prey graphs. J Ecol 63:459-481

Panizzo VN, Jones VJ, Birks HJB, Boyle JF, Brooks SJ, Leng MJ (2008) A multiproxy palaeolimnological investigation of Holocene environmental change, between c. 10700 and 7200 years BP, at Holebudalen, southern Norway. Holocene 18:805-817

Paul CA, Rühland KM, Smol JP (2010) Diatom-inferred climatic and environmental changes over the last $\sim 9000-$ years from a low Arctic (Nunavut, Canada) tundra lake. Palaeogeogr Palaeoclimatol Palaeoecol 291:205-216

Pienitz R, Smol J, MacDonald G (1999) Paleolimnological reconstruction of Holocene climatic trends from two boreal treeline lakes, Northwest Territories, Canada. Arct Antarct Alp Res 31:82-93

Randsalu-Wendrup L, Conley DJ, Carstensen J, Snowball I, Jessen C, Fritz SC (2012) Ecological regime shifts in Lake Kälksjön, Sweden, in response to abrupt climate change around the $8.2 \mathrm{ka}$ cooling event. Ecosystems 15:13361350

Rasmussen P, Anderson N (2005) Natural and anthropogenic forcing of aquatic macrophyte development in a shallow Danish lake during the last 7000 years. J Biogeogr 32:1993-2005

Reuss NS, Hammarlund D, Rundgren M, Segerström U, Eriksson L, Rosén P (2010) Lake ecosystem responses to holocene climate change at the subarctic tree-line in Northern Sweden. Ecosystems 13:393-409

Reuss NS, Anderson NJ, Fritz SC, Simpson GL (2013) Responses of microbial phototrophs to late-Holocene environmental forcing of lakes in south-west Greenland. Freshw Biol 58:690-704

Rouillard A, Michelutti N, Rosén P, Douglas M, Smol JP (2012) Using paleolimnology to track Holocene climate fluctuations and aquatic ontogeny in poorly buffered High Arctic lakes. Palaeogeogr Palaeoclimatol Palaeoecol 321-322:1-15

Rühland K (2001) Diatom assemblage shifts relative to changes in environmental and climatic conditions in the circumpolar treeline regions of the Canadian and Siberian Arctic. PhD thesis, Queen's University, Kingston, ON

Rühland K, Paterson AM, Smol JP (2008) Hemispheric-scale patterns of climate-related shifts in planktonic diatoms from North American and European lakes. Glob Change Biol 14:2740-2754

Saros JE, Stone JR, Pederson GT, Slemmons KEH, Spanbauer T, Schliep A, Cahl D, Williamson CE, Engstrom DR (2012) Climate-induced changes in lake ecosystem structure inferred from coupled neo- and paleoecological approaches. Ecology 93:2155-2164

Sayer CD, Hoare DJ, Simpson GL, Henderson ACG, Liptrot ER, Jackson MJ, Appleby PG, Boyle JF, Iwan Jones J, Waldock MJ (2006) TBT causes regime shift in shallow lakes. Environ Sci Technol 40:5269-5275

Sayer CD, Davidson TA, Iwan Jones J, Langdon PG (2010a) Combining temporary ecology and palaeolimnology to understand shallow lake ecosystem change. Freshw Biol 55:487-499

Sayer CD, Burgess A, Kari K, Davidson TA, Peglar S, Yang H, Rose N (2010b) Long-term dynamics of submerged macrophytes and algae in a small and shallow, eutrophic lake: implications for the stability of macrophyte-dominance. Freshw Biol 55:565-583

Scheffer M, Carpenter SR (2003) Catastrophic regime shifts in ecosystems: linking theory to observation. Trends Ecol Evol 18:648-656

Scheffer M, Jeppesen E (2007) Regime shifts in shallow lakes. Ecosystems 10:1-3

Scheffer M, van Nes EH (2007) Shallow lakes theory revisited: various alternative regimes driven by climate, nutrients, depth and lake size. Hydrobiologia 584:455-466

Scheffer M, Hosper S, Meijer M, Moss B, Jeppesen E (1993) Alternative equilibria in shallow lakes. Trends Ecol Evol $8: 275-279$

Scheffer M, Straile D, van Nes EH, Hosper H (2001a) Climatic warming causes regime shifts in lake food webs. Limnol Oceanogr 46:1780-1783

Scheffer M, Carpenter S, Foley JA, Folke C, Walker B (2001b) Catastrophic shifts in ecosystems. Nature 413:591-596

Schindler D, Knapp R, Leavitt P (2001) Alteration of nutrient cycles and algal production resulting from fish introductions into mountain lakes. Ecosystems 4:308-321

Seekell DA, Cline TJ, Carpenter SR, Pace ML (2013) Evidence of alternate attractors from a whole-ecosystem regime shift experiment. Theor Ecol 6:385-394

Smol JP, Douglas MSV (2007) From controversy to consensus: making the case for recent climate using lake sediments. Front Ecol Environ 5:466-474

Smol JP, Wolfe AP, Birks HJB, Douglas MSV, Jones VJ, Korhola A, Pienitz R, Rühland K, Sorvari S, Antoniades D, Brooks SJ, Fallu MA, Hughes M, Keatley BE, Laing TE, Michelutti N, Nazarova L, Nyman M, Paterson AM, Perren B, Quinland R, Rautio M, Saulnier-Talbot E, Siitoneni S, Solovieva N, Weckström J (2005) Climate-driven regime shifts in the biological communities of arctic lakes. Proc Natl Acad Sci USA 102:4397-4402

Stevens LR, Stone JR, Campbell J, Fritz SC (2006) A 2200-yr record of hydrologic variability from Foy Lake, Montana, USA, inferred from diatom and geochemical data. Quat Res 65:264-274 
Stone J, Fritz S (2004) Three-dimensional modeling of lacustrine diatom habitat areas: improving paleolimnological interpretation of planktic: benthic ratios. Limnol Oceanogr 49:1540-1548

Theissen KM, Hobbs WO, Hobbs J (2012) The altered ecology of Lake Christina: a record of regime shifts, land-use change, and management from a temperate shallow lake. Sci Total Environ 433:336-346

Wang R, Dearing JA, Langdon PG, Zhang E, Yang X, Dakos V, Scheffer M (2012) Flickering gives early warning signals of a critical transition to a eutrophic lake state. Nature 492:419-422

Weyhenmeyer G, Meili M, Livingstone DM (2004) Nonlinear temperature response of lake ice breakup. Geophys Res Lett 31:L07203
Williams JW, Blois JL, Shuman BN (2011) Extrinsic and intrinsic forcing of abrupt ecological change: case studies from the late Quaternary. J Ecol 99:664-677

Williamson CE, Saros JE, Schindler DW (2009) Sentinels of change. Science 323:887-888

Wilson CR, Michelutti N, Cooke CA, Briner JP, Wolfe AP, Smol JP (2012) Arctic lake ontogeny across multiple interglaciations. Quat Sci Rev 31:112-126

Zimmer KD, Hanson MA, Herwig BR, Konsti ML (2009) Thresholds and stability of alternative regimes in shallow Prairie-Parkland Lakes of Central North America. Ecosystems 12:843-852 